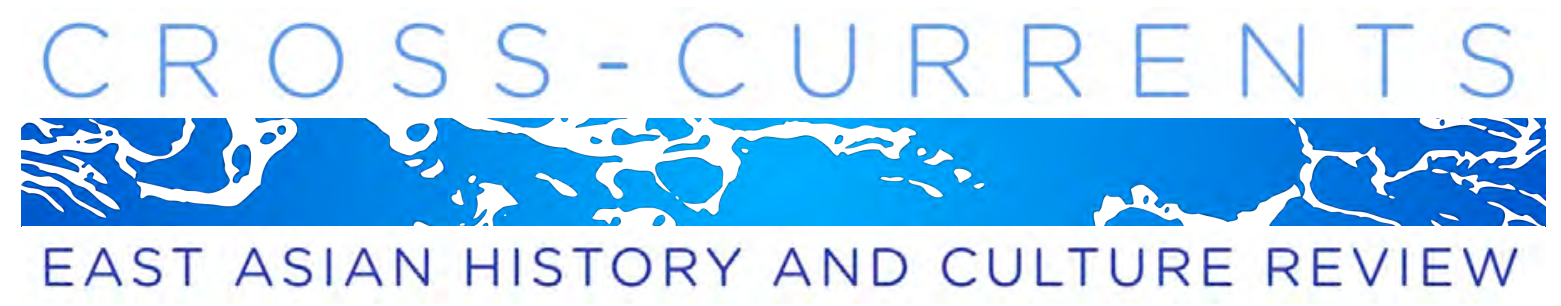

\title{
Cartographic Anxieties in Mongolia: The Bogd Khan's Picture-Map
}

Uranchimeg Tsultemin, University of California, Berkeley

\begin{abstract}
:
This article extends cartography into ethnographic and representational practices for territorial inclusion (Hostetler 2005) and nation building (Krishna 1994). Outer Mongolia, a vassal state of the Qing Empire until 1911, produced ethnographic paintings intended as new cartographic visuals around the time of its independence. Mongolia's last ruler, the Bogd Khan (1870-1924) commissioned the artist Balduugin Sharav to produce a large painting of the Mongol countryside titled Daily Events, a work that constitutes an unusual cartographic "picture-map" (Paul Harvey 1980) intended for a special public display. The work (now known as One Day in Mongolia) depicts the Mongolian people as a distinct ethnic group in quotidian scenes of Central Mongolian (Khalkha) nomadic life. This article demonstrates how the covert connections between the scenes together construct a Buddhist didactic narrative of the Wheel of Life, and argues that this picture-map was the result of the Tibetan-born ruler's anxieties over ethnic identity, national unity, and the survival of his people, who strove for independence from the Qing, as well as their safe positioning vis-à-vis new political neighbors.
\end{abstract}

Keywords: Bogd Gegeen, Bogd Khan, Jetsundampa Khutukhtu, Sharav, Mongolian painting, Mongolian Buddhist art, Khalkha

\section{Anxieties, Cartography, and Picture-Maps}

In her book Qing Colonial Enterprise, Laura Hostetler suggests that ethnographic illustrations made during the late Qing period were in fact maps designed to serve the goals of Qing expansionist politics. She argues that cartography, such as that employed to produce atlases, was used to map out the territory of the empire inclusive of non-Chinese peoples, while ethnographic pictures-including the Qing Imperial Illustrations of Tributaries and the Miao albums - were also "symbolic maps of those peoples who comprised, or at least recognized, the Qing empire" (Hostetler 2005, 205). 
However, maps and ethnographic pictures were not always made with such expansionist goals of inclusion. Or were they? How, for instance, did ethnographic illustrations function as maps if they were produced by those frontier people (i.e., the Miao) themselves, without the court's involvement? How did conquered peoples ${ }^{1}$ envision themselves in their ethnographic pictures, and if such pictures were maps — symbolic or cartographic-what use did they have? The dynamics of inside-outside and border-center-periphery relations take an interesting and revealing turn when one considers certain painted pictures, mostly landscapes seen from above, as maps produced outside of the Qing's immediate influence.

This article focuses on Khalkha Mongolia, a vassal state of the Qing since the seventeenth century, ${ }^{2}$ where ethnographic illustrations, picture-maps, and cartographic atlases were all abundantly produced during the late Qing period. ${ }^{3}$ The variety of cartographic genres in Mongolia recalls the apparent parallel between maps and paintings in Chinese map-making. According to Cordell Yee, genres in Chinese cartography have been a compelling issue, questioning the boundary between cartographic and artistic traditions throughout Chinese history (Yee 1994, 139). Similarly, the Mongolian visual representation analyzed in this article is both cartographic and artistic.

In his discussion of medieval Italian mapping practices, Paul Harvey described the landscapes of Florence seen from a bird's-eye view as "picture-maps" of a particular locale, its surroundings, and its people (Harvey 1980). Unlike "pictorial maps" (i.e., Hearn 2009), which were produced as maps and included only landscape and topography, the "picture-map," as defined by Harvey, was inherently a picture - a landscape, in most cases - and its cartographic aspects were only implied. This is also the case with the painting titled One Day in Mongolia, considered to be the masterpiece of Mongolian art in the early twentieth century (figure 1). In this article, I examine this famous illustration as a "picture-map" that offers broader perspectives on the mapping practices of rulers and their artists in the context of political and social transition.

One Day in Mongolia was produced in Ikh Khüree, Outer Mongolia's capital and home to its quintessential monastery, by a Tibetan-born Mongol reincarnate ruler, the Eighth Jetsundampa Agwaan-Luvsan-Choiji-Nyima-Danzan-Wanchug (T. Rje btsun dam pa Ngag dbang blo bzang chos kyi nyi ma bstan 'dzin dbang phyug), known as the Bogd Gegeen (lit. Holy Saint) and Bogd Khan (1870-1924), during the first years of his theocratic reign (1911- 
1921). ${ }^{4}$ As the story goes, the Bogd Gegeen commissioned his favorite artist, Balduugin Sharav (1869-1939), to create, with the assistance of other artists, pictures of the Mongolian countryside outside of Ikh Khüree. The artists produced two large paintings, which were titled Daily Events (Damdinsüren 1993, 62). Both paintings have survived and are kept in Ulaanbaatar's Zanabazar Fine Arts Museum, yet new names were created for each of them: One Day in Mongolia and Airag Feast. ${ }^{5}$ While elsewhere I discuss the two paintings together, for this special issue of Cross-Currents, I aim to explore and highlight two particular aspects of One Day in Mongolia: its mapping of the Khalkha and the unique coherence of its narrative around the Buddhist Bhavacakra, or Wheel of Life. My reading of the Bhavacakra in this painting, a feature also mentioned earlier by two historians of Qing Mongolia, Johan Elverskog (2004) and Françoise Aubin (2012), is based primarily on visual analysis, and therefore remains speculative until new archival sources are found to bring other perspectives for new readings of this painting. ${ }^{6}$

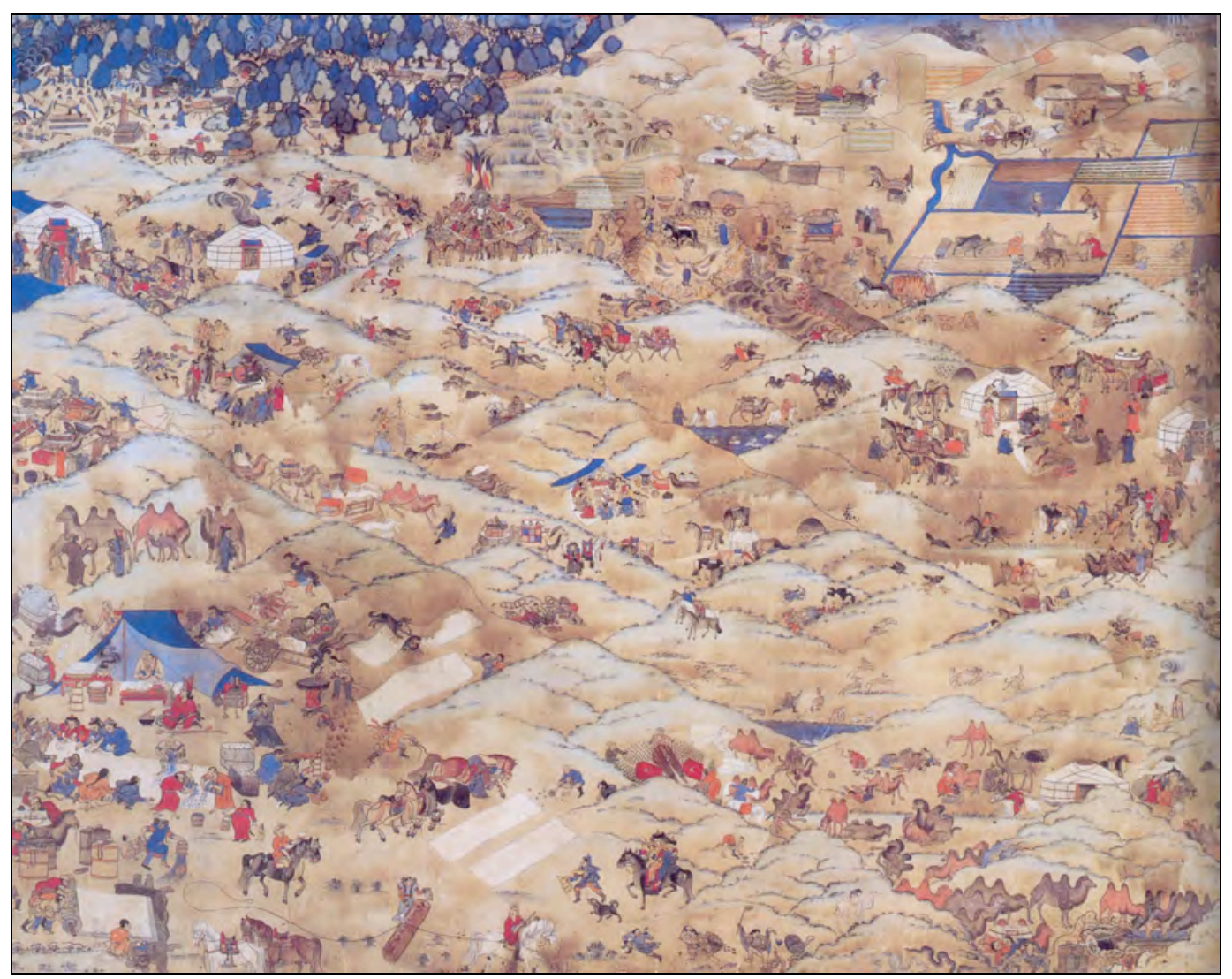

Cross-Currents: East Asian History and Culture Review

E-Journal No. 21 (December 2016) • (http://cross-currents.berkeley.edu/e-journal/issue-21) 
Figure 1. One Day in Mongolia by B. Sharav, 1912-1915. Mineral pigments on cotton, $135 \mathrm{x}$ $170 \mathrm{~cm}$. Source: Zanabazar Museum of Fine Arts, Ulaanbaatar, Mongolia.

The analysis and discussion of this painting has remained limited, despite its fame and frequent reproduction, which showcases it as a "masterpiece" of presocialist Mongolian art. One Day in Mongolia has been discussed by several scholars, but only in terms of its ethnographic and folkloric value. ${ }^{7}$ The painting consists of numerous vignettes of daily life, and scholars have tended to treat its scenes separately as indicative of a particular time, season, or activity, with the depiction of felt making, for example, suggesting summer. ${ }^{8}$ However, this painting is unusual not only in its ethnographic detail, but also in its style, its narrative composition (which includes secular themes of daily life), and its public display. Aubin has suggested that we see Sharav's painting in the Chinese narrative painting tradition marked by Song dynasty painter Zhang Zeduan's (張擇端, 1085-1145) famous hand scroll Along the River during Qingming Festival (Aubin 2012, 470), a work that depicts busy streets and landscapes of Kaifeng. Two decades earlier than Aubin, Mongolian art historian D. Dashbaldan alleged that he saw similarities between Sharav's work and Netherlandish Renaissance painter Pieter Bruegel's (1525-1569) peasant scenes (Dashbaldan 1988, 1993). However, it is hardly possible that a twelfth-century Chinese artist, a sixteenth-century Dutch artist, and an early twentieth-century Mongolian artist actually influenced one another. Examples of manuscript illustrations, quite widespread in Sharav's time, and didactic illustrations for teaching the Dharma — the Prajñāpāramitā Sūtra, for example (Kollmar-Paulenz 2012)—show Mongolian styles affiliated with Tibetan thangka paintings.

Another Khalkha Mongolian named Lodoi, who was active in Inner Mongolia in 1938, also painted scenes of the countryside. ${ }^{9}$ However, these smaller and simpler compositions were not picture-maps reminiscent of One Day in Mongolia and thus are not representative of the Buddhist themes explored in this article. Monk-artist Sharav's closest inspirations were likely Buddhist didactic narratives, such as jātakas and avadānas, that share his work's wit, humor, and accessible subject matter. While most paintings at the time were made for temples and Buddhist rituals, Sharav's painting was publicly displayed in a specially prepared location right outside the ruler's palace (Damdinsüren 1993, 62). Given the painting's high degree of visibility, 
I wonder how its particular ethnic focus and unique narrative was understood by its viewers and conveyed the Bogd Gegeen's cartographic anxieties during the tumultuous politics in Inner Asia.

Because no archival information about this unusual painting survives from the Bogd Gegeen's times, I rely on his own texts and the writings of a former Ikh Khüree monk-artist named D. Damdinsüren to shed light on its context and production. As the painting was made during the first years of the Bogd Khan's theocratic period in 1912-1915 (Damdinsüren 1993; Aubin 2012), just after Mongolia gained its long-awaited independence from the Qing in 1911, I consider it imperative to look into the volatile milieu of political transformation, transition, and the formation of Mongolia's national identity vis-à-vis its new neighbors. In similar situations elsewhere, cartographic metaphors and references are frequently used tropes that reveal anxiety about the unity and survival of a nation, as Sankaran Krishna has shown in his analysis of cartographic manifestations used in a postcolonial India suspended in the space between "former colony" and "not-yet-nation" (Krishna 1994). Krishna's definition of cartography is worth quoting, as it forms the main framework for my discussion:

By cartography I mean more than the technical and scientific mapping of the country. I use the term to refer to representational practices that in various ways have attempted to inscribe something called India and endow that entity with a content, a history, a meaning, and a trajectory. Under such a definition, cartography becomes nothing less than the social and political production of nationality itself. $(1994,508)$

Cartographic references appear to have been the necessary means in the Bogd Khan's nationbuilding enterprise. Using Krishna's definition, we shall see how One Day in Mongolia is an example of cartography, as the painting was made during a contested era of transition when the anxiety over Mongolia's national unity and identity and threats to its integrity were particularly acute.

\section{Ethnic Focus and Quotidian Realities}

In One Day in Mongolia, Sharav arranges numerous scenes of the Mongolian countryside in one large composition using variable perspectives and a bird's-eye view. Divided by hills, each scene presents a familiar event of daily life specific to Mongol nomads: hunting, moving a 
ger (yurt), traveling by camel caravan, making felt, worshipping mountains (M. ovoo takhikh), engaging in shamanistic rituals, chanting prayers, and so on. The entire composition lays out a panoramic view of nomadic life as one dazzling scene. A former monk-artist of Ikh Khüree describes how the Bogd Gegeen gathered several artists and instructed them to go in all four directions and depict "everything they saw on their way" (Damdinsüren 1995, 57) — that is, to collect ethnographic information about ordinary people's lives similar to the Qing ways of assembling ethnographic materials for the production of the Miao albums. In the Mongolian case, however, the "others" were not foreign peoples targeted for forceful inclusion. This meticulous attention to the direct, on-site observation of common people suggests the ruler's aims to define his realm and gain a comprehensive and iconic representation of nomadic life.

Sharav, a member of Bizya aimag, ${ }^{10}$ was originally from Gobi-Altai, but moved from the countryside to Ikh Khüree at the age of twenty-two (Aubin 2012, 469). The Bogd Gegeen is said to have had a special connection with the artist. A popular legend describes how the two first found mutual trust through the ruler's testing of Sharav's talent. Allegedly, the Bogd Gegeen asked Sharav to paint a thousand elephants on a square paper the size of a töo (the distance between thumb and forefinger), recalling an earlier tale in which the Kangxi Emperor (康熙 1654-1722) tested the virtuosity of the First Jetsundampa Zanabazar (1635-1723), an eminent Mongol artist, in a similar manner. ${ }^{11}$ Sharav is said to have painted eight hundred elephants, which satisfied and pleased the khan, bonding the two as a patron and his favorite artist.

As a southerner who had moved to the northern monastery of Ikh Khüree, Sharav was able to refer visually to the different geographical zones in central Mongolia inhabited mostly by the Khalkha. The top register of the painting refers to the northern zone, known for its rich stands of dense woods. The western part of the country, prominent with mountain ranges and shamans, is contrasted with the east, which is rather plain and flat topographically, here indicated by vast crop fields. The southern Gobi regions are represented at the bottom with dominant figures of camels, with the large scene showing felt production placed in the southwest.

One Day in Mongolia shows people in ethnic clothes that identify them as Khalkha Mongols (figure 2). According to Christopher Atwood's definition,

Khalkha Mongols are the major subethnic group (yastan) of the independent State of Mongolia, or Outer Mongols.... Khalkha dialect is the standard language of 
Mongolia. The native Khalkha are virtually the sole ethnic group in Mongolia's vast rural interior; only in the border areas are other ethnic groups significant. $(2004,299)$

The painting does not depict Chinese peddlers or other ethnic populations, such as the Tibetans and Russians who were living in Mongolia at that time. ${ }^{12}$

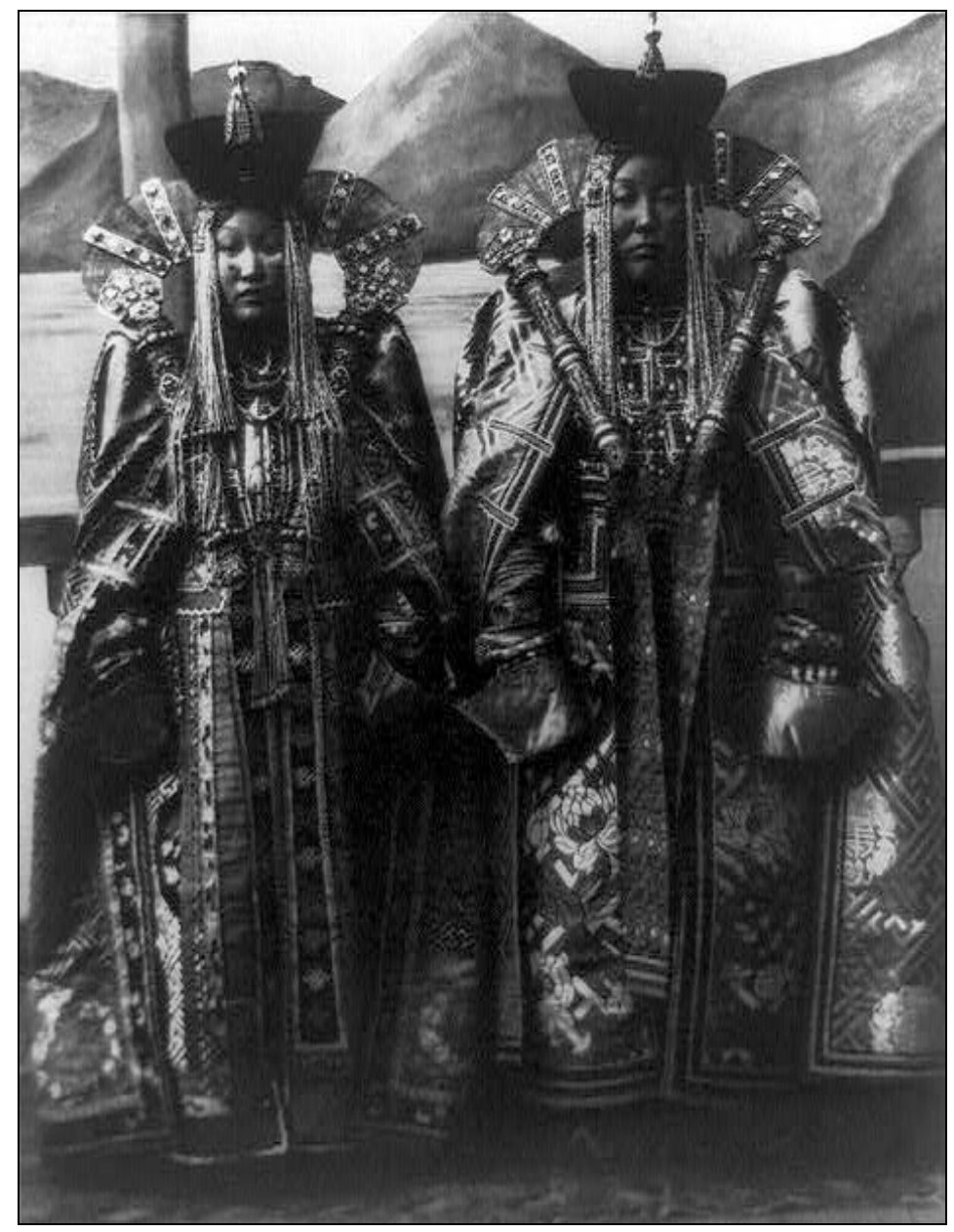

Figure 2. Khalkha women, c. 1920. Source: Library of Congress, Prints and Photographs Division.

While the clothing, especially the uniquely shaped headdresses worn by married women, clearly identifies the Khalkha in the painting, the events and activities depicted are common to nomads in general. If the ruler's other maps, such as one by the artist Jügder (figure 3), were restricted to only Bogd Khan's main seat, Ikh Khüree, and its environs, in the case of Sharav's 
work the artist and patron extended their vision to the entire Khalkha territory (encompassing all of the central regions in Mongolia) as the definitive, timeless place and space of the nomadic world.

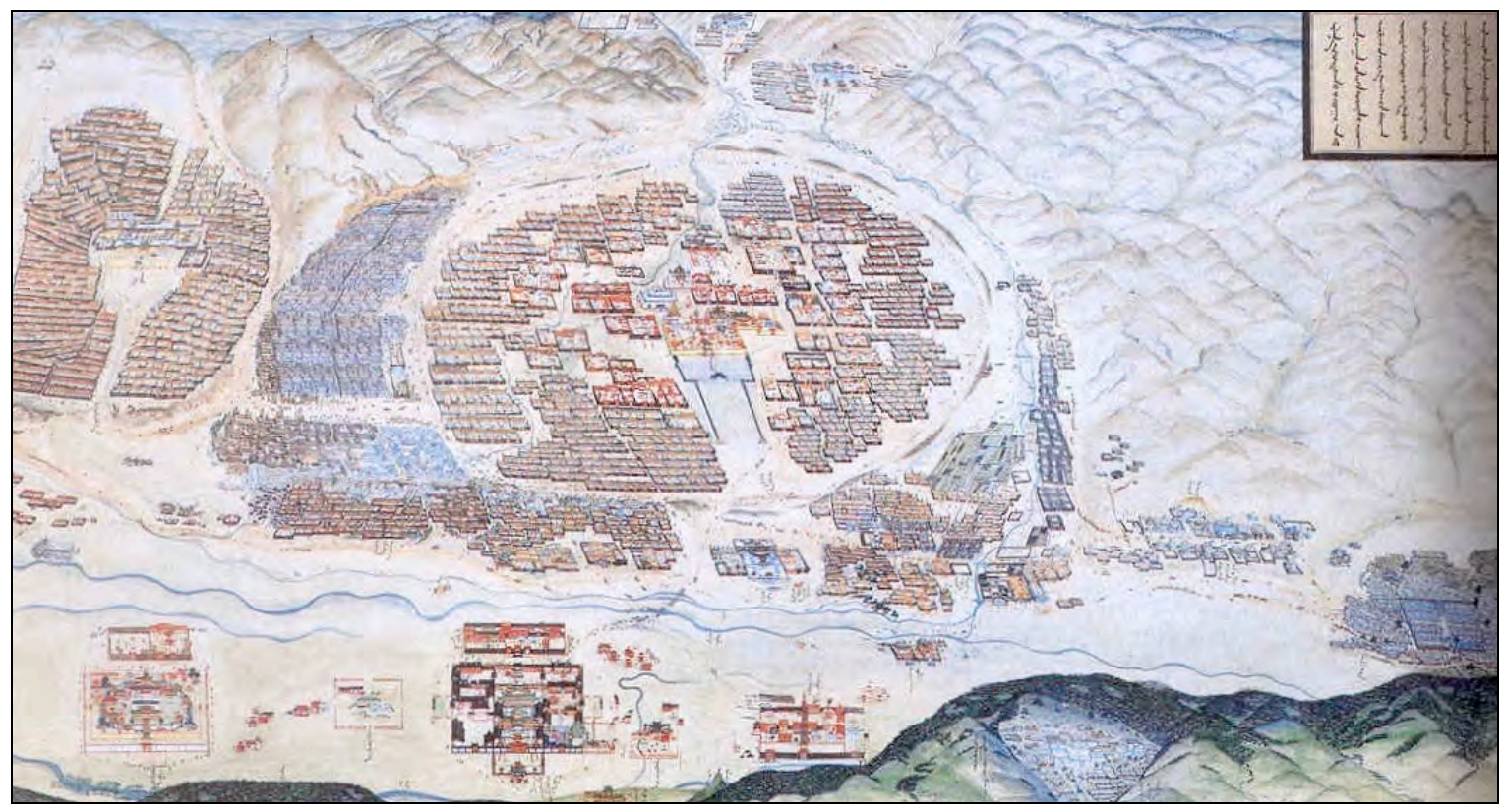

Figure 3. Capital Ikh Khüree by Jügder, 1912. Mineral pigments on cotton. Source: Bogd Khan Palace Museum.

A vassal region of the multiethnic, polyglot Qing Empire, Mongolia was divided into inner and outer regions based on the Qing division of territorial and subethnic banners. ${ }^{13}$ The Khalkha, claiming the majority of Outer Mongolia, was long ruled by the Buddhist reincarnate (T. sprul sku), Jetsundampa Khutukhtu, a lineage imported from Tibet in the seventeenth century and endorsed by the Qing court. ${ }^{14}$ The Eighth Jetsundampa, however, was the only one to receive the status of khan, the ruling title of Mongol pedigree. It is no wonder, then, that the Bogd Khan, a Tibetan-born ruler, was anxious to have Sharav paint the Khalkha as representatives of the "nomadic" Mongol world to highlight its distinctness vis-à-vis its southern Han Chinese neighbor.

During the first two decades of the twentieth century, when this painting was made, the dynastic histories of Mongolia and its two neighbors - China and Russia - were in the process of 
a tragic and violent ending. The Tsarist Russian government was replaced by the Bolshevik Revolution in 1917, and the millennia-old imperial China was struck by the Xinhai Revolution (辛亥革命) in 1911-1912. In these early years of the new century, the Bogd Gegeen reached out to international powers - such as Russia, Japan, and the United States - to request support for Mongolia's independence from the Qing. ${ }^{15}$ Even before the Chinese Wuchang Uprising (武昌起義) in October 1911, the Bogd Gegeen approved Mongolian nobles' aspirations to request military assistance from Tsarist Russia to further their shared nationalist goals (Bawden 1989, 193-194). At the pinnacle of the Xinhai Revolution, on December 29, 1911, Outer Mongolia proclaimed its independence from the Qing, and the Eighth Jetsundampa was chosen by the Khalkha nobility to be the All-Inaugurated ${ }^{16}$ (M. Olnoo Örgögdsön; Skrt. Mahāsammata) khan of Mongolia. By 1914, the Bogd Khan had five ministries in his theocratic government.

Sharav's painting demonstrates that the Khalkha, which had been governed for two centuries by a Buddhist ruler brought from Tibet via the Qing court and supervised and controlled by a Manchu government amban (high official) installed in Ikh Khüree since the eighteenth century (see Ochir and Enkhtuvshin 2003, 163; Ichinnorov 1998, 11; Rupen 1957, 159; Pozdneev 1896-1898, 67), was now proclaiming itself as the single Mongolian identity; the painting made it more than a visual statement. International treaties signed by multiple parties recognized Outer Mongolia as the territory in the "Russian and Japanese spheres of influence" (Ewing 1980, 542; Campi and Baasan 2009, 473n26; Baabar [Batbayar] 1999, 246) or under the sovereignty of China, while Inner Mongolia was marked as an integral part of China (Campi and Baasan 2009, 6). ${ }^{17}$ In 1915, the tripartite Treaty of Kyakhta was signed by China, Mongolia, and Russia to rectify Chinese suzerainty over Outer Mongolia (Bawden 1989, 200-201; Campi and Baasan 2009, 6-7). ${ }^{18}$ Tibet, China's other neighbor and former vassal state of the Qing, also struggled for its independence during these years. Tibet's leader, the Thirteenth Dalai Lama (Thub bstan rgya mtsho, 1876-1933), arrived in Mongolia on November 27, 1904, after fleeing Colonel Francis Younghusband's punitive expedition into Tibet; he subsequently left Mongolia for Wutaishan in northeastern China in the late spring of 1907 (Shakya 2005, 143-144; Rockhill [1891] 1975, 62-63). Mongolia and Tibet signed a historical treaty recognizing each other's independence in 1913 (see Sperling and Tuvshingtugs 2013, especially 7-29). This treaty was 
the single document that unconditionally recognized Mongolia's (and Tibet's) independence during the Bogd Khan's theocratic period.

In addition to these international treaties and Mongolia's difficulty in having its independence recognized by its neighbors, an increasing number of Chinese settlements in Mongolia during this time were seen as a real threat to unity and independence. ${ }^{19}$ The Bogd Gegeen's writings include instructions, prophecies, and regulations with nationalistic sentiments specifically referring to the avoidance of all things Chinese. Consider, for example, the following excerpts from an 1892 epistle by the Eighth Jetsundampa Khutukhtu to the Khalkha and other Mongol tribes:

This is the decree of Heaven: The black headed Chinese became many and they reached the extremes of disorder, that is why the compassionate Buddha should remember the many Mongols who believe with faith in the religious teaching.... Do not eat goat meat, chicken meat and eggs. Do not buy Chinese tobacco!... You must not drink Chinese brandy....

But, if you do not believe this order of mine, your morals will decline and you will die together with the Chinese. From the first of the fourth month do not go to office with them. Do not eat grain and do not live together with them. Do not talk to them.

If a Mongol wears a white hat and Chinese boots and lives like the Chinese, he will die together with the Chinese. (Sárkőzi 1992, 129-132)

As Atwood notes, while the Mongolian views of the Manchu and the Qing were different and reflected a vision of the latter as Inner Asian peoples (2004, 299), the Bogd Gegeen had to grapple with both the Manchu and the Chinese. The carefully selected pictorial language of One Day in Mongolia underscores the ruler's anxiety at a time when dramatic events were shaping new political borders. Unlike the Qing Miao albums, this picture-map is not concerned about the inclusion of other ethnic groups. Yet it is similar to the Miao albums in that it resorts to an ethnographic visual language based on direct observation. The nature of the events depicted does not reflect anything to indicate the theocratic period itself — or any period, for that matter - but the painting maps out the timeless presence of Khalkha nomads "hill after hill," as one Mongolian saying goes. Quotidian realities, publicly displayed outside of the Bogd Khan's palace, aim to convey self-awareness and national unity as a visual statement to support and enhance the ruler's written instructions. 


\section{The Picture-Map as a Wheel of Life}

One Day of Mongolia is a large composition that at first appears disorganized and scattered. However, it is easy to read in a continuous manner, as the artist carefully organized the painting by distributing larger vignettes of full events with many figures in the four corners and connecting them with the movement of horsemen horizontally and diagonally across the picture plane.

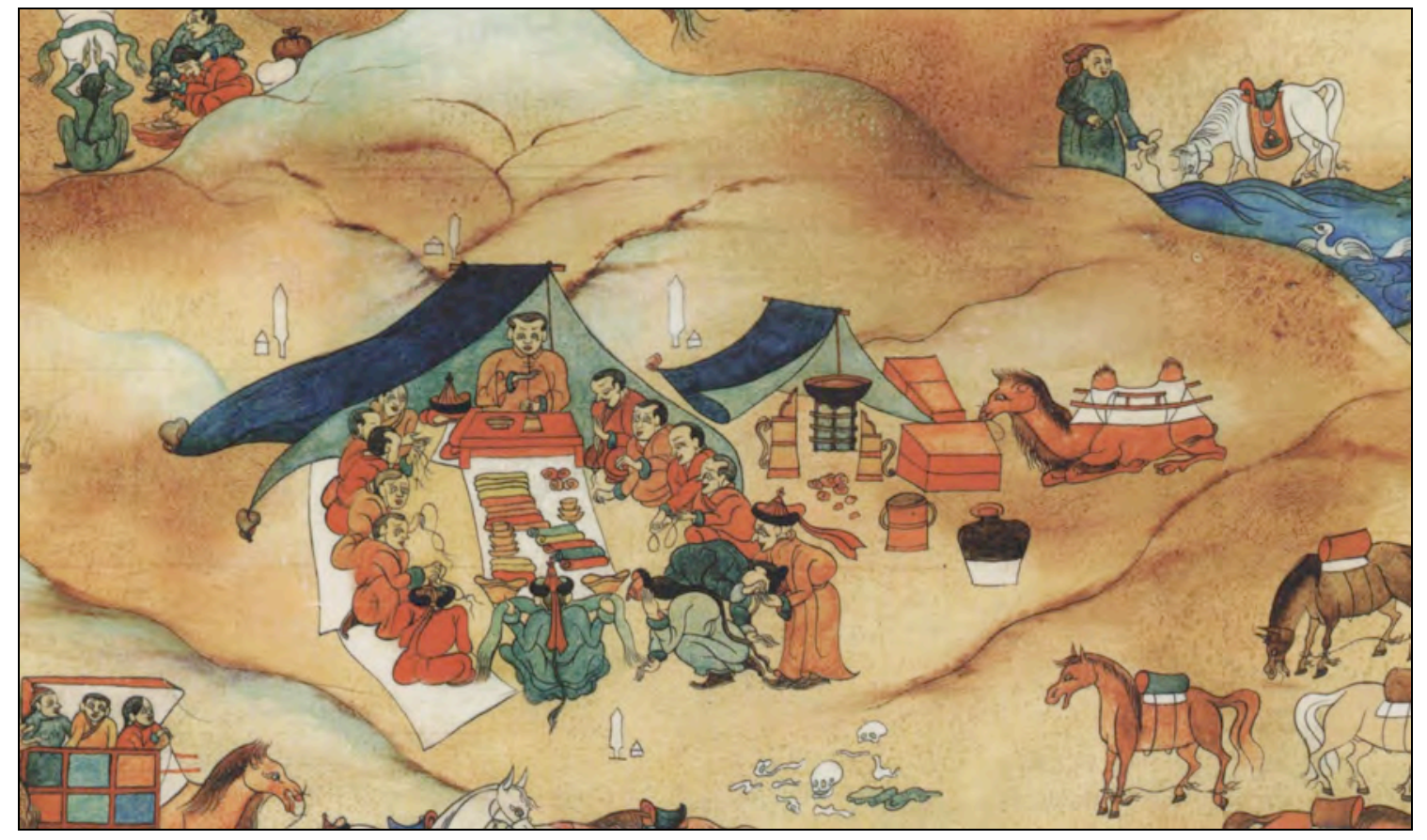

Figure 4. Lama's funerary ritual. Central detail in One Day in Mongolia.

At the center of the painting is a visually separate and distinctive tent with a Buddhist teacher (lama, guru; T. bla ma) performing a ritual for a group of people seated in front of him (figure 4). This placement causes the other scenes to appear to be distributed around him. A close look shows bones scattered around, suggesting death. All around the lama are people and families moving across the hills, covering vast distances: at the same eye level, two potent scenes 
of marriage negotiators and a relocating family with a camel caravan move toward each other, halting at the lama's ritual, highlighting his centrality. The marriage is divided into several parts: a galloping group carrying a covered bride moves from the right while the actual marriage takes place in the top left, connecting two parts of the composition almost diagonally. The relocating family reappears again in the bottom right setting up a new ger (yurt), thus eloquently suggesting continuity in spatial and temporal distance. This movement across the painting is another creative compositional ploy to guide the viewing trajectory and to pull the scattered narrative together.

In many ways, the painting is indiscreet, humorous, and shocking with its numerous details. The most intimate moments of human life-such as scenes of giving birth inside a ger, defecating in the open air, disturbing incidents of domestic violence, drunken and fighting men, and a male and female couple openly engaging in sexual intercourse - are presented alongside other mundane, everyday activities. There is no discrimination in the depiction of these scenes, with the most intimate moments as well as public and team-based events all laid out in one panoramic view. As the artists were monks who, according to Vinaya regulations, are restricted from participating in worldly activities, they looked for specific details in the rural countryside for a visual representation that forms a narrative. The painting deliberately shows a witty mix of lay life with monastic life, to the extent that it seems like an inevitable bond.

The two east-west movements of the family relocation and the marriage converge at the central point of the lama, whose position in the middle of the composition suggests that the life of movement and (re)production culminates in the lama's ritual. Here, he is invited to mourn with the family over the dead, eloquently reminding viewers of the Buddhist concept of impermanence of life and the illusion of things and suffering, with skulls and human bones scattered in front of the ritual space. Placing the funerary scene at the center and visually emphasizing the discourse of death is a clever artistic device to keep the image legible in mundane terms for public viewing, and also to educate ordinary viewers on the essentials of Buddhist doctrine through literal and straightforward depiction.

The obvious and logical connectedness of scenes, such as those showing marriage, sexual intercourse, and birth, generates a continuous narrative that is developed through what appear at first glance to be separate scenes. These direct indices of the cyclicality of birth, life, and death, 
followed by ideas of production and consumption through activities such as felt making, harvesting, chopping trees in the woods, and the like, inevitably bring to mind the Bhavacakra, the Buddhist Wheel of Life.

The composition does not literally take the form of a circle, nor does it follow the sequential division and structure that binds the Buddhist concepts deployed in the conventional depiction of the Bhavacakra (figure 5). Thus, we do not find demarcated realms of gods (devās), demi-gods (äsuras), hungry ghosts (prētas), or hell; only the human realm is depicted, closely mingled with the realm of animals. However, the core Buddhist ideas of the Bhavacakra, with its didactic meaning pointing to the correlation of cause and effect, are tangentially expressed in multifarious ways. 


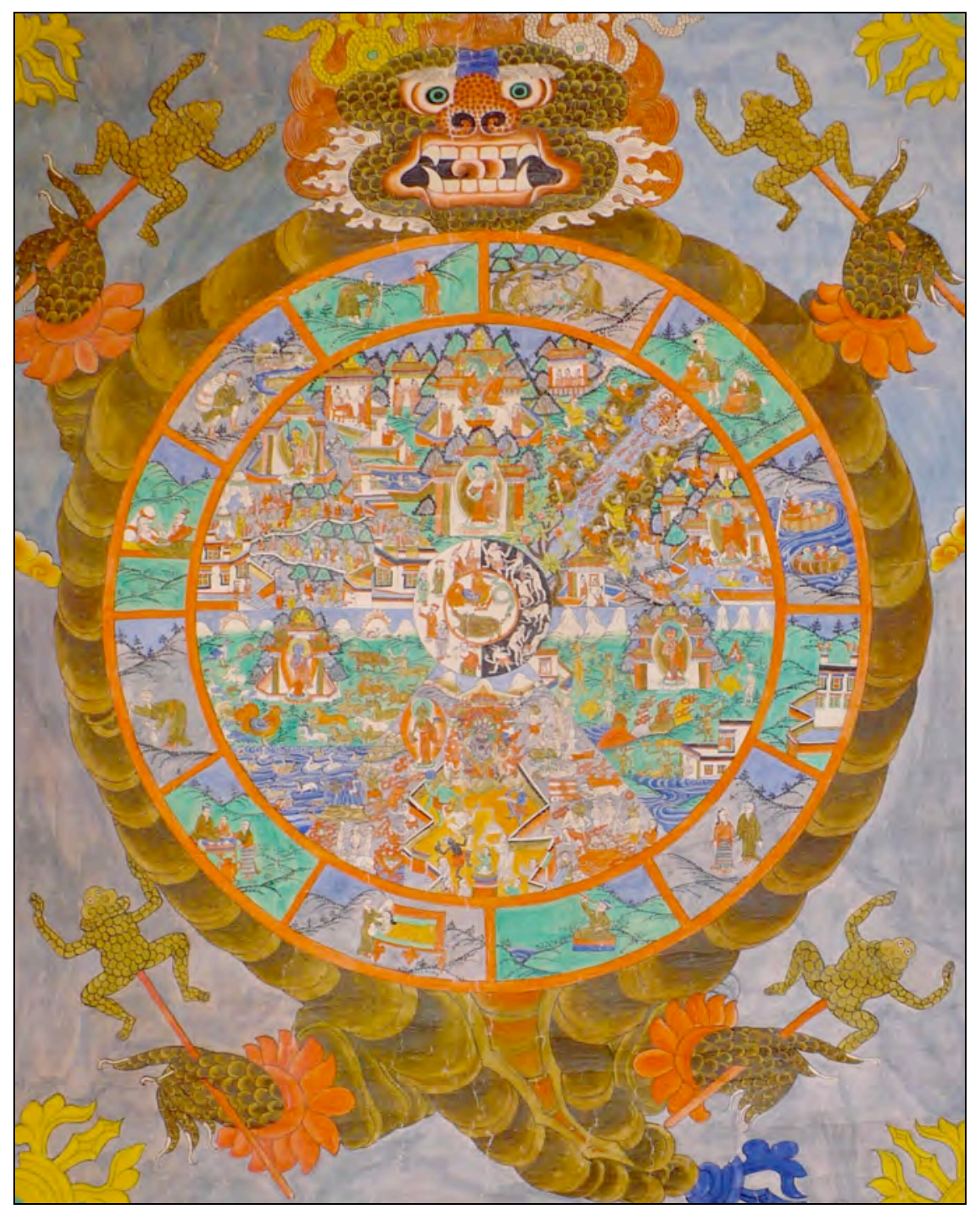

Figure 5. Bhavacakra, the Buddhist Wheel of Life. Thangka painting, Central Tibet, late nineteenth century. Source: Theos Bernard-Eleanor Murray collection, BAMPFA.

Here, the human labor that aims to secure the necessary supplies for living is represented in literal terms. However, these representations also depend on volitional conditioning (mental formation, or saíkhāra), which opens doors onto all of the scenes depicted in relationship to one another: from rituals to marriage, building a home, and the conception of new life. It is deliberate, then, that the artist places the marriage scene right underneath the scene of the harvesting of crops, thereby annexing the volitional formation, saikhāra, with the next link of causal dependence, as the marriage is based on the consciousness (vijñana) of the two families 
involved and reconciled. The young girl forcefully taken as a bride (figure 6), on the other hand, appears to serve here as a visual metaphor for ignorance (avidya), which is usually represented in traditional depictions of the Bhavacakra as a blind man with a stick. The departure of the bride is the condition that leads visually in two directions - to the scene of entering a new ger (name and form, or namarüpa) in the top left (figure 7) and to the sensual activities of sexual intercourse and birth (figure 8) - to represent several links of dependent-arising (pratityasamutpāda) in Bhavacakra: contact (sparśa), sensation (vedanā), craving (tanhhā), grasping (upādāna), becoming (bhāva), and birth (jāti).

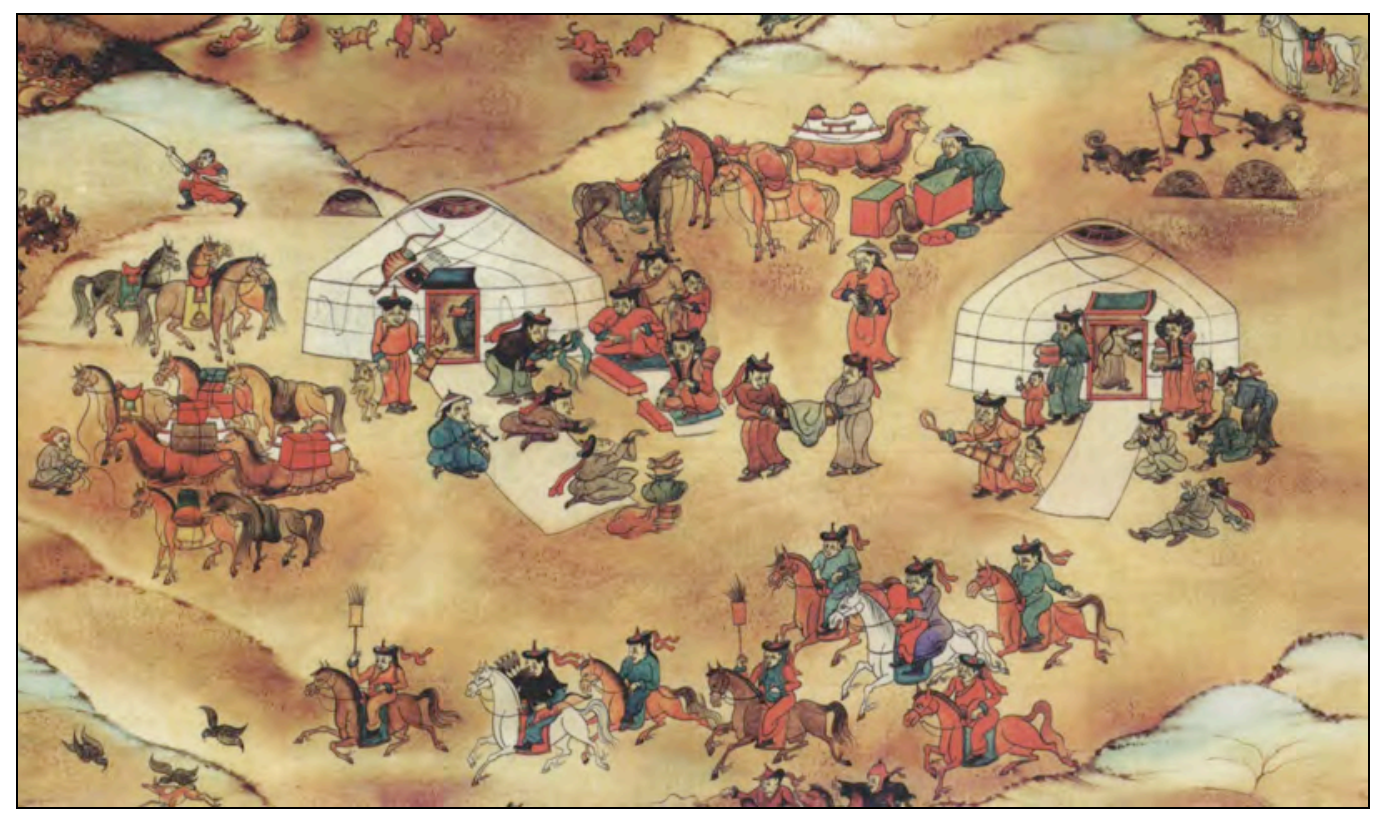

Figure 6. Detail. Marriage negotiation: Bride is taken away from parents' home. 


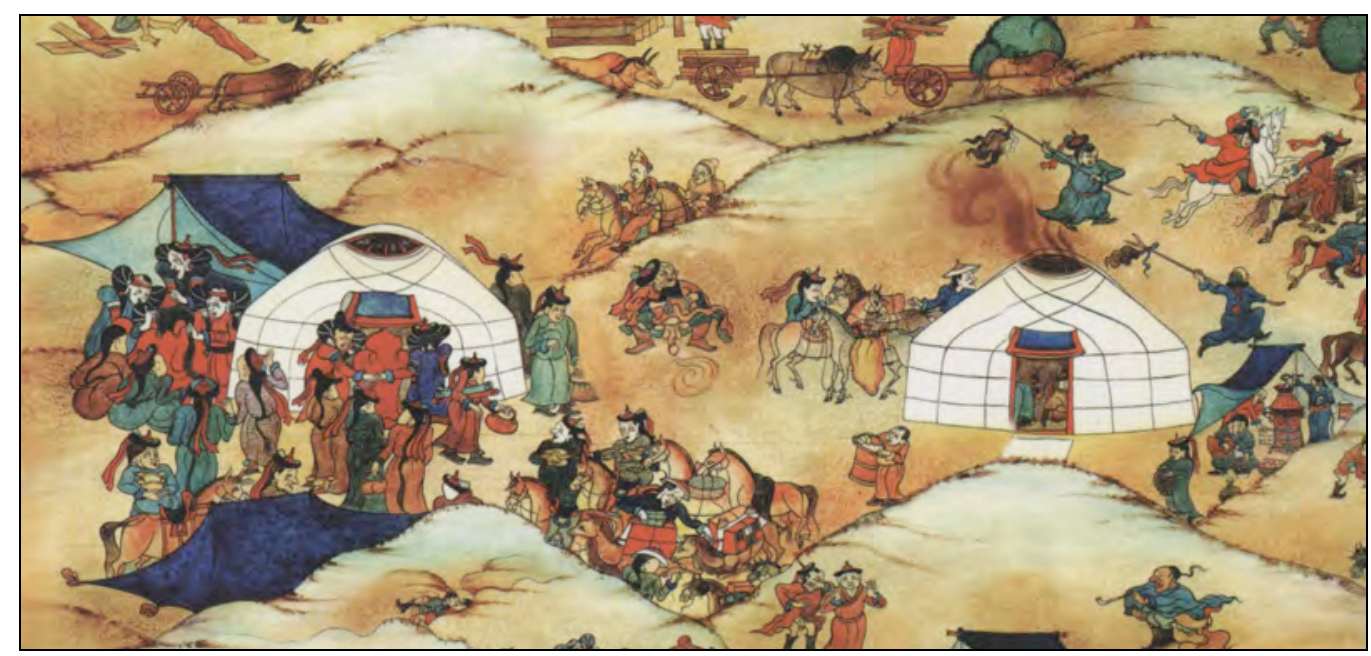

Figure 7. Detail. Marriage ends: Bride enters new home. Wedding.

The girl, now a woman burdened with children, is riding to the next scene of felt making (figure 8), which represents another act of creating a condition. We see a scene of a couple embracing and kissing under a newly made piece of felt, symbolizing once again contact (sparśa), sensation (vedanā), and craving. The painting does not elaborate on every causality link separately; rather, it presents an easily readable narrative that aims to highlight the message of cause and effect- "dependence upon conditions, in reliance upon conditions, through the force of conditions" (Gyatso [2000] 2015, 35) - showing explicitly how all culminate in the image of the lead teacher and the central message of impermanence and death.

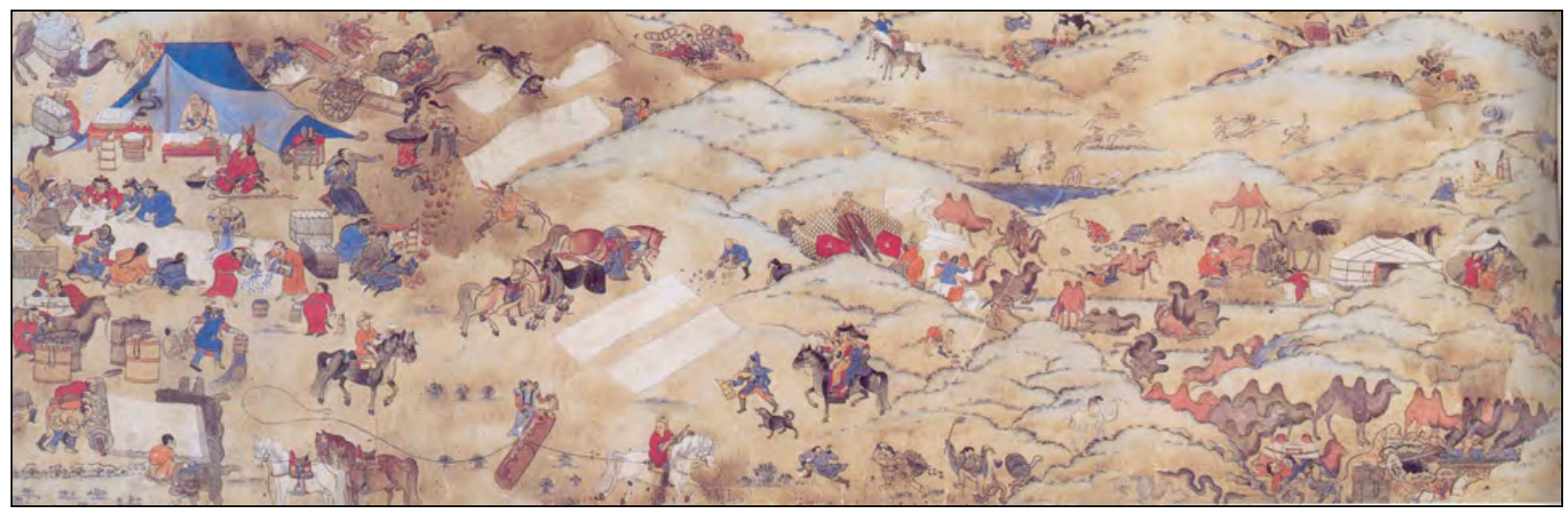

Figure 8. Detail. Intercourse and giving birth. Woman with children and felt production. 
With its readable and familiar scenes flavored with wit and humor, the linked narrative of the painting has been constructed specifically to engage the viewer in the full dynamics of viewing, so that he or she can both comprehend and enjoy the visual narrative. If conventional Buddhist paintings, and specifically the traditionally depicted Bhavacakra, offer symbolically charged imagery that is impossible to follow without proper training and a teacher's guidance, this particular "Wheel of Life" is specifically designed to be comprehensively viewed by ordinary people on their own. Sharav and the Bogd Gegeen, the artist and the patron, aimed for a construction of the Wheel of Life that is very different from what Stephen Teiser has described as the "non-narrative art" of traditional Wheel of Life paintings, where "the viewing experience involves discriminating between the different parts of the composition and learning their symbolic value, not following a story" (Teiser 2006, 267). In this case, not only does the viewer comprehensively decipher the meaning, but he or she also effortlessly projects himself or herself into the narrative of Buddhist teaching, where the teacher is the center of the ritual. This active engagement with the picture by reading and enjoying the narrative is akin to that elicited by the stories of jātaka and avadāna: the viewer does not need explanations of the content but grasps the core ideas based on his or her own capacities of thinking and imagination. The main principle of these visual narratives is not to provide information, but to stimulate creative thinking, discursive viewership, and active involvement with visual language. As this unique representation of the Wheel of Life was produced during a time of political instability, the Bogd Khan's own writings further explain the timeliness of Buddhist concepts for common comprehension.

The Bogd Gegeen repeatedly stated the following in his numerous writings:

Evil times are coming. All over the world savage times are coming to accumulate all evil. My fellow Mongolians, aspire for good through your faith and remove evil. From the Year of Rat (1924) suffering and disaster will be even harder. ${ }^{20}$

The Year of Rat that the Bogd Gegeen indicates is 1924, which suggests that he was predicting a future that would indeed be particularly harsh with the establishment of a new socialist government after his death in 1924. In these upcoming destructive years, the Bogd Gegeen visually instructs his diverse subjects to rely on the core essentials of Buddhist Dharma 
and to stand in national unity as the only way toward liberation. He expresses similar ideas in his writings of jarliү (instructions):

Oh, my northern Khalkhas! In this time of deterioration, if you accept this teaching of mine, none of your dangerous, evil enemies will be able to gather, you will escape from the fears.... In this time of deterioration, if you trust the lama master, the time when you may enter the land of Buddha is not far. ${ }^{21}$

One Day in Mongolia allows the viewer to follow from one scene to another, reading the events in the sequential narrative; the uncomplicated worldliness of the scenes helps him or her to realize how phenomena are empty of inherent existence. Therefore, as the Fourteenth Dalai Lama instructs, "In order to reflect on the fact that things - the subjects upon which a meditator reflects - are empty of inherent existence, it is necessary to identify the subjects of this reflection: the phenomena that produce pleasure and pain, help and harm, and so forth" (Gyatso [2000] 2015, 36). This painting, then, is not only an ethnographic mapping of the Khalkha, but also a didactic and alternative Wheel of Life that continuously engages its viewers in reading and meditating on fundamental Buddhist teachings, especially pertinent during the unstable time of foreign threats to Mongolia's independence.

One Day in Mongolia demonstrates that the Bogd Gegeen's interest in images was not limited to visually mapping out "the territory... as a resource to be dominated or controlled by a political center," as was the case, according to Hostetler (2005, 16), in Qing China. Using a single ethnographic focus and mapping the Khalkha Mongolia, this cartographic representation is a powerful response to the anxieties of national unity at the time of its liberation and fragile independence. While this map is a visual statement of timeless space and place distinct of its own homogeneity, the antinomy of inside-outside also serves, as Krishna put it, "to discipline and produce the "domestic(ated) self" (Krishna 1994, 513). Quotidian realities in this Mongolian map are used to enhance the arbitrariness in the production of normality that has been claimed back in the efforts of the Bogd-and with him the Mongol nobility - to hegemonize the territory. ${ }^{22}$ In this sense, the cartographic anxieties that triggered the production of One Day in Mongolia indicate Mongolia's in-between transitional status toward the modern construction of a nation and nationality and, with that, new epistemological means in the search of the self. The 
change of its original title from Daily Events to One Day in Mongolia during the socialist period reveals that these cartographic anxieties remained acute even decades later, into the modern day.

Uranchimeg Tsultemin is a lecturer in History of Art and a co-chair of the Mongolia Initiative at the University of California at Berkeley. She would like to express her sincere gratitude to Franck Billé for inviting her to contribute to this special issue of Cross-Currents, and for his patience and kindness in communications for this purpose. She is also grateful to the journal's anonymous reviewers for their important comments, which helped her to further develop this article.

\section{Notes}

$1 \quad$ Here I am using the term conquered in a general sense to refer to non-Han Chinese populations that were annexed to the Qing by various means, including conquering. The Khalkha Mongols were not necessarily "conquered" peoples, however, as they swore allegiance to the Qing in 1691.

2 Different parts of Mongolia fell to the Qing at different times. The earliest was Inner Mongolia, which became part of the Qing in 1636; the Khalkha swore alliance in 1691, and the Western Dzungar Mongols were subjugated by the Qing by 1739 .

3 Many banner maps were also produced in Inner and Outer Mongolia. For examples, see the banner and monastery maps at the National History Museum, the Zanabazar Museum of Fine Arts, and the Bogd Khan Palace Museum in Ulaanbaatar.

4 As the argument presented in this article is also projected into the modern anxieties of Mongolia, I will use the contemporary title of the painting as well as the transcription of modern-day Cyrillic Mongolian for Mongolian terms.

5 The two paintings are also known as Summer and Autumn. See Tsultem (1986). The Zanabazar Museum uses the title One Day of Mongolia to translate to English its Mongolian title "Mongolin neg ödör."

6 Johan Elverskog (2004) briefly mentions this idea but does not discuss it. Françoise Aubin $(2012,469-470)$ also mentions the idea that the Bhavacakra is implicit in the painting.

7 These writers include: Lomakina (1974, 124-125), Sonomtseren (1969), and Tsultem (1986, 1988). The most recent are Batchuluun (2009) and Aubin (2012).

8 See, for example, Aubin (2012, 469-470).

9 Lodoi's pictures are currently held at the National Museum of Denmark in Copenhagen (see Haslund-Christensen [1996]). Other Inner Mongolian narrative paintings include: a painting from Ordos, dated c. 1860 and preserved in the Scheut Museum in Belgium (Yang [1995]); a painting titled Life in the Steppe from Shilingol (Qing dynasty, Museum of Inner Mongolia, see Wang, Shi, and Xie 1999); a Picture of the Ö̈ld depicting pastoralism; manuscript paintings; and so on.

10 An aimag is a monastic community, reminiscent of a Tibetan Gelug khantsen (T. khang tshan), or regional monastic house. 
11 In that story, Kangxi asks Zanabazar to carve sixteen arhats (enlightened beings) on a ruby the size of a thumbnail. See Bawden $(1961,49)$.

12 According to Ivan Maiskii, there were 542,500 Mongols, 100,000 Chinese, and 5,000 Russians in Khalkha Mongolia. For more on Mongolia in the early twentieth century, see Maiskii (1921).

13 For more on banners, see Atwood (2004, 30-32).

14 The Jetsundampa (T. rJeb tsun dam pa) lineage was imported from Tibet in the seventeenth century within political interests of the Qing court, Khalkha Mongol nobility, and Tibetan Gelug (T. dGe lugs) order. Altogether there were eight Jetsundampa reincarnate rulers in Mongolia; only the first two were Mongolian-born, and the rest were brought from Tibet. There are several publications of Jetsundampa hagiographies. See fully annotated translations in Bawden (1961); Baasan (2011); and Bareja-Starzyńska (2015).

15 As Alicia Campi has recently shown, the Bogd Gegeen sent various requests to the United States asking for support (Campi and Baasan 2009, 60-63, 69-73, 111). For Bogd's letters to Japan, see O. Batsaikhan's several papers, including his "Letter of Bogd Javzandamba to His Excellency Emperor of Japan" and "Bogdin Zasgiin Gazrin Yapontoi Hariltsah gesen Gurvan Oroldlogo" [Three attempts of the Bogd's government to communicate with Japan], all available at www.academia.edu, retrieved May 8, 2016. Also see Batsaikhan (2013, chap. 4).

16 In other translations, this is rendered as "Elevated by Many." See Batsaikhan (2008).

17 I. Korostovets, a Russian minister in Beijing who spent nine months in Ikh Khüree in 1912-1913, signed a treaty with Republican China in 1913. See more in Batsaikhan, Bakich, and Tatsuo (2009).

18 According to Christopher Atwood, the Kyakhta treaty was largely written by Russia. About one-third of Mongolia's national budget and all of its military equipment came from Russia. Due to such financial dependence on Russia, Mongolia was forced to sign the treaty for Chinese suzerainty. See more in Atwood (2004, 324).

19 Bawden $(1989,91)$ mentions that a special "colonization bureau" was established in Ikh Khüree in 1911.

20 From the Boyda Jibjundamba-yin surjal (Bogdo Jebtsundamba's admonitions). The translation is mine.

21 From the Boyda gegegen-ü lündüng (Bogd Gegeen’s prophesies). See Sárkőzi (1992, 126).

22 Krishna uses quotidian realities to show the violence of imposing borders and reveal the postcolonial preoccupation with national space in India. He calls it an obsession; this cartographic anxiety, according to Krishna, is one symptom of the postcolonial condition (1994, 514, 517).

\section{References}

Atwood, Christopher. 2004. Encyclopedia of Mongolia and the Mongol Empire. New York: Facts on File. 
Aubin, Françoise. 2012. "Patrimoine artistique et réécriture du passé dans la Mongolie du XXe siècle" [Artistic heritage and rewriting the past in twentieth-century Mongolia]. Anthropos 107: 467-480.

Baabar (Batbayar), B. 1999. History of Mongolia. Winwick, UK: White Horse Press.

Baasan, D., transl. (Anonymous author). 2011. Bogd Javzandamba Hutagt [Bogd Jetsundampa Khutugtu]. Ulaanbaatar: Mönhiin üseg Press.

Bareja-Starzyńska, Agata. 2015. The Biography of the First Khalkha Jetsundampa Zanabazar by Zaya Pandita Luvsanrinlei. Warsaw: Faculty of Oriental Studies, University of Warsaw.

Batchuluun, L. 2009 Marzan Sharavin Tuurvil zui [The lyric creation of Marzan Sharav]. Ulaanbaatar: Syomobo Printing.

Batsaikhan, O. 2008. Mongolin suulchin ezen khan VIII Bogd Javzandamba [Mongolia's last khan, the Eighth Jetsundampa]. Ulaanbaatar: Admon.

- 2013. Mongolia: Becoming a Nation-State. Ulaanbaatar: Bitpress.

Batsaikhan, O., Olga Bakich, and Nakami Tatsuo, eds. 2009. Ivan Yakovlevich Korostovets: Deviat' mesyatsov v Mongolii [Ivan Yakovlevich Korostovets: Nine months in Mongolia]. Ulaanbaatar: Academy of Sciences.

Bawden, Charles. 1961. The Jebtsundamba Khutukhtus of Urga. Wiesbaden: Otto Harrassowitz. . 1989. The Modern History of Mongolia. New York: Kegan Paul International.

Bogd Javzandamba Hutagt [Bogd Jetsundampa Khutugtu]. (1800s) 2011. Translated by D. Baasan. Ulaanbaatar: Mönhiin üseg Press.

Boyda Jibjundamba-yin surjal [Bogd Jetsundampa’s admonitions]. Manuscript. Mongolian National Library.

Campi, Alicia J., and R. Baasan. 2009. The Impact of China and Russia on United StatesMongolian Political Relations in the Twentieth Century. Lewiston, NY: Edwin Mellen Press.

Damdinsüren, D. 1993. Ikh Khüreenii nert urchuud [Eminent artists of Ikh Khüree]. Ulaanbaatar: Mongolpress.

Dashbaldan, D. 1988. Uran Zurag, orchin uye [Painting and modernity]. Ulaanbaatar: Publisher unknown.

- 1993. Dursljekh Urlagijn Muzei-Musée des Beaux-Arts-Fine Arts Museum: UlaanBataar. Ulaanbaatar: Findakli Hjevlelijn Gazar.

Elverskog, Johan. 2004. "Things and the Qing: Mongol Culture in the Visual Narrative." Inner Asia 6 (2): 137-178.

Ewing, Thomas. 1980. Between the Hammer and the Anvil: Chinese and Russian Policies in Outer Mongolia, 1911-1921. Indiana University Uralic and Altaic Series 138.

Bloomington: Indiana University Press.

Gyatso, Tenzin (14th Dalai Lama). (2000) 2015. The Wheel of Life: Buddhist Perspectives on Cause and Effect. Translated and edited by Jeffrey Hopkins. Boston, MA: Wisdom Publications.

Harvey, Paul. 1980. The History of Topographic Maps: Symbols, Pictures and Surveys. London: Thames and Hudson.

Haslund-Christensen, Henning. 1996. "Meeting a Mongol Artist.” Mongolian Studies 19: 51-57. 
Hearn, Maxwell. 2009. "Pictorial Maps, Panoramic Landscapes, and Topographic Paintings: Three Modes of Depicting Space during the Early Qing Dynasty." In Bridges to Heaven: Essays on East Asian Art in Honor of Professor Wen C. Fong, edited by Jerome Silbergeld, Dora C. Y. Ching, Judith G. Smith, and Alfreda Murck, 93-114. Princeton: Tang Center for East Asian Art and Princeton University Press.

Hostetler, Laura. 2005. Qing Colonial Enterprise: Ethnography and Cartography in Early Modern China. Chicago, IL: University of Chicago Press.

Ichinnorov, S., ed. 1998. Öndör Gegeen Zanabazar [Zanabazar]. Ulaanbaatar: Mongolian Academy of Sciences.

Kollmar-Paulenz, Karénina. 2012. "Teaching the Dharma in Pictures: Illustrated Mongolian Books of the Ernst Collection in Switzerland." In The Arts of Tibetan Painting: Recent Research on Manuscripts, Murals and Thangkas of Tibet, the Himalayas and Mongolia (11th-19th century), edited by Amy Heller. PIATS 2010: Proceedings of the Twelfth Seminar of the International Association for Tibetan Studies, Vancouver, 2010. Available at http://www.asianart.com/articles/iats/index.html, accessed November 3, 2016.

Krishna, Sankaran. 1994. "Cartographic Anxiety: Mapping the Body Politic in India." Alternatives 19:507-521.

Lomakina, I. 1974. Marzan Sharav [Funny Sharav]. Moscow: Izobrazitel'noe iskusstvo.

Maiskii, Ivan M. 1921. Sovremennaya Mongolia [Modern Mongolia]. Irkutsk: Irkutskoe otdelenie.

Ochir A., and B. Enkhtuvshin, eds. 2003. History of Mongolia. Vol. 4. Ulaanbaatar: Institute of History, Mongolian Academy of Sciences.

Pozdneev, Alexei M. 1896-1898. Mongoliya i Mongoli [Mongolia and the Mongols]. St. Peterburg: Tipografiia Imperatorskoi akademii nauk.

Rockhill, William W. (1891) 1975. The Land of the Lamas: Notes of a Journey through China, Mongolia, and Tibet. New Delhi: Asian Publication Services.

Rupen, Robert. 1957. "The City of Urga in Manchu Period." In Studia Altaica: Festschrift für Nicholas Poppe, 157-169. Wiesbaden: Otto Harassowitz.

Sárkőzi, Alice. 1992. Political Prophesies in Mongolia in the 17-20th Centuries. Budapest: Akadémiai Kiadó.

Shakya, Tsering. 2005. "The Thirteenth Dalai Lama.” In The Dalai Lamas: A Visual History, edited by Martin Brauen, 136-161. Chicago, IL: Serindia Publications/Ethnographic Museum of the University of Zurich.

Sonomtseren L. 1969. Uran Zuraach B. Sharav [Artist B. Sharav]. Ulaanbaatar: Mongolin Urchuudin Evlel.

Sperling, Elliot, and R. A. Tuvshingtugs, eds. 2013. The Centennial of the Tibeto-Mongol Treaty: 1913-2013. Lungta Series 17. Dharamsala: Amnye Machen Institute.

Teiser, Stephen. 2006. Reinventing the Wheel: Paintings of Rebirth in Medieval Buddhist Temples. Seattle: University of Washington Press.

Tsultem, Nyam-Osoryn. 1986. Development of the Mongolian National Style Painting "Mongol Zurag” in Brief. Ulaanbaatar: Gosizdatel'stvo. 
1988. Mongol Zurgiin Khugjij irsen tuuh [The history of the development of Mongol Zurag]. Ulaanbaatar: Mongolin Urchuudin Evlel.

Yang Haiying. 1995. "Une toile.” Courrier Verbiest Courier 1 (June), 9-11.

Yee, Cordell. 1994. "Chinese Cartography among the Arts: Objectivity, Subjectivity, Representation." In The History of Cartography, edited by John B. Harley and David Woodward, 2: 139-152. Chicago, IL: University of Chicago Press.

Wang Yongqiang, Shi Weimin, and Xie Jianyou, eds. 1999. Wang yǒngqiáng, shǐwèimín, xièjiànyóu, zhōngguó shăoshù mínzú wénhuà shǐ tú diăn 王永強, 史卫民, 谢建猷, 中国少 数民族文化史图典 [Album of cultural history of Chinese minorities]. Nanning: Museum of Inner Mongolia. 